\title{
Pharmacological Specialization of Learned Auditory Responses in the Inferior Colliculus of the Barn Owl
}

\author{
Daniel E. Feldman and Eric I. Knudsen \\ Department of Neurobiology, Stanford University School of Medicine, Stanford, California 94305
}

Neural tuning for interaural time difference (ITD) in the optic tectum of the owl is calibrated by experience-dependent plasticity occurring in the external nucleus of the inferior colliculus (ICX). When juvenile owls are subjected to a sustained lateral displacement of the visual field by wearing prismatic spectacles, the ITD tuning of ICX neurons becomes systematically altered; ICX neurons acquire novel auditory responses, termed "learned responses," to ITD values outside their normal, preexisting tuning range. In this study, we compared the glutamatergic pharmacology of learned responses with that of normal responses expressed by the same ICX neurons. Measurements were made in the ICX using iontophoretic application of glutamate receptor antagonists. We found that in early stages of ITD tuning adjustment, soon after learned responses had been induced by experience-dependent processes, the NMDA receptor antagonist D,L-2-amino-5-phosphonopentanoic acid (AP-5) preferentially blocked the expression of learned responses of many ICX neurons compared with that of normal

The NMDA subtype of glutamate receptor has been implicated in experience-dependent plasticity in a wide range of developing systems (Constantine-Paton et al., 1990; Shatz, 1990). Although its exact role in this process remains elusive, the predominant view is that, by analogy with NMDA receptor function in longterm potentiation (LTP) and depression (LTD) at CA1 hippocampal synapses (Collingridge and Bliss, 1987; Dudek and Bear, 1992; Mulkey and Malenka, 1992; Kirkwood et al., 1993), the NMDA receptor participates in experience-dependent plasticity as a detector of correlated activity, the activation of which leads to the induction of changes in synaptic efficacy (Bear et al., 1987; Constantine-Paton et al., 1990; Cline, 1991; Katz and Shatz, 1996).

A role for NMDA receptors in the expression, as distinct from the induction, of experience-dependent plasticity has been described recently in the auditory space-processing pathway of the barn owl (Feldman et al., 1996). In the external nucleus of the inferior colliculus (ICX) of the owl, auditory responses are mediated by glutamate receptors, with both NMDA and nonNMDA receptor subtypes being routinely activated by acoustic

\footnotetext{
Received Dec. 12, 1997; revised Jan. 30, 1998; accepted Feb. 3, 1998.

This work was supported by Grant 5 R01 DC 00155-17 from the NIDCD, National Institutes of Health, and by National Institutes of Health Training Grant 2T32 NS $07158-18$ to D.E.F.

Correspondence should be addressed to Dr. Eric I. Knudsen, Department of Neurobiology, Fairchild Building, Stanford University School of Medicine, Stanford, CA 94305-5125.

Dr. Feldman's present address: Department of Psychiatry, Langley Porter Psychiatric Institute, Box 0984, University of California, San Francisco, CA 94143.

Copyright (C) 1998 Society for Neuroscience $0270-6474 / 98 / 183073-15 \$ 05.00 / 0$
}

responses of the same neurons. In contrast, the non-NMDA receptor antagonist 6-cyano-7-nitroquinoxaline-2,3-dione (CNQX) blocked learned and normal responses equally. After long periods of prism experience, preferential blockade of learned responses by AP-5 was no longer observed. These results indicate that NMDA receptors play a preferential role in the expression of learned responses soon after these responses have been induced by experience-dependent processes, whereas later in development or with additional prism experience (we cannot distinguish which), the differential NMDA receptor-mediated component of these responses disappears. This pharmacological progression resembles the changes that occur during maturation of glutamatergic synaptic currents during early development.

Key words: sound localization; experience-dependent plasticity; inferior colliculus; silent synapses; NMDA receptors; development

stimuli (Feldman and Knudsen, 1994). ICX neurons are sharply tuned for interaural time difference (ITD), a cue for the horizontal location of a sound source, and are arranged into a map of ITD. ITD tuning is adaptively altered when juvenile owls wear prismatic spectacles that cause a sustained lateral displacement of the visual field (Brainard and Knudsen, 1993). This alteration in ITD tuning is observed in both the ICX and the optic tectum, which receives a major auditory input from the ICX, but not in the lateral shell of the central nucleus of the inferior colliculus (ICCls), which provides auditory input to the ICX (Fig. 1A). Thus, changes in neural circuits that underlie ITD tuning modification are thought to occur in the ICX itself (Brainard and Knudsen, 1993).

During prism rearing, ICX and tectal neurons acquire novel responses, termed "learned responses," to ITD values outside of their normal ITD tuning range (Feldman et al., 1996). At many sites, learned responses appear before responses to the normal ITD range, termed "normal responses," disappear, creating transition state ITD tuning curves that contain both types of responses (Fig. 1B). In a previous study (Feldman et al., 1996), the pharmacology of ICX circuits mediating normal and learned responses was compared by measuring the effects of glutamate receptor antagonists applied in the ICX on transition state ITD tuning recorded downstream in the tectum. The results indicated that both normal and learned responses in the ICX were glutamatergic, but that NMDA receptors in the ICX preferentially mediated the expression of learned responses relative to normal responses.

Although the method of recording responses in the tectum 


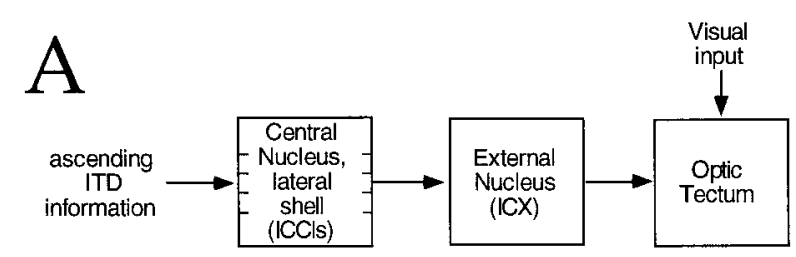

B
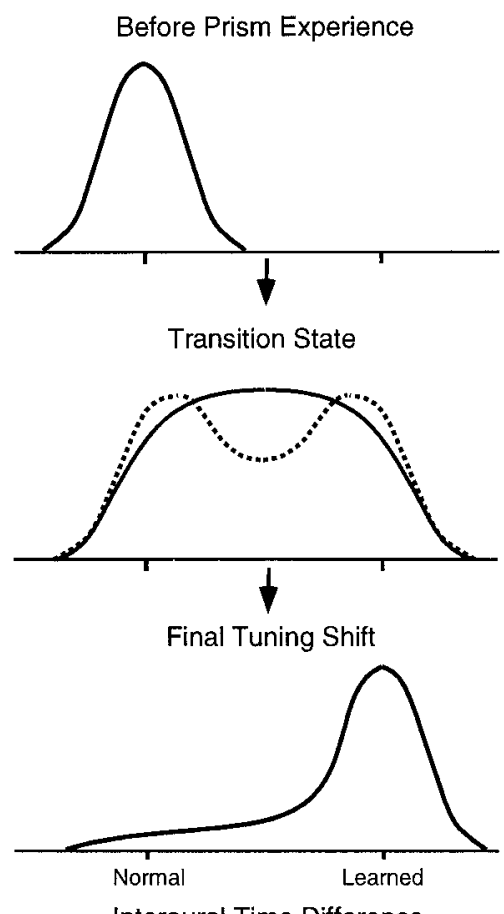

Interaural Time Difference

Figure 1. ITD pathway to the optic tectum and modification of ITD tuning by prism experience. $A$, ITD pathway to the optic tectum. The ICCls projects topographically to the ICX (Wagner et al., 1987), which in turn projects topographically to the optic tectum (Knudsen and Knudsen, 1983). Horizontal tick marks indicate tonotopic organization, used to distinguish the ICCls from the ICX. $B$, Schematic stages of ITD tuning modification in the ICX and tectum during prism experience. Before prism attachment, ITD tuning for each recording site is centered around a best ITD value (Normal) that is systematically related to anatomical location in the ICX and to the visual receptive field azimuth for sites in the tectum (Feldman and Knudsen, 1997). After a few weeks of prism experience, ICX and tectal neurons acquire novel responses to ITD values displaced from the normal value by an amount corresponding to the optical displacement of the prisms (Learned). Learned and normal responses are coexpressed at many sites to create transition state ITD tuning, which can be broad or even double-peaked (Brainard and Knudsen, 1995). With additional prism experience, normal responses are greatly reduced.

allows normal and learned auditory responses to be identified accurately from the visual receptive field location of a unit (Olsen et al., 1989; Brainard and Knudsen, 1993), this technique is limited in that it provides only indirect measurements of the pharmacological effects occurring in the ICX. As a result, the magnitude of the pharmacological differences between learned and normal responses could not be measured directly, nor could it be ascertained whether the pharmacologically distinct circuits converge at the level of single neurons in the ICX. Moreover, pharmacological measurements were made after only short periods of prism experience, so it could not be determined whether the differential contribution of NMDA receptors to learned responses occurred only transiently during the learning process or was a permanent characteristic of abnormal, learned responses.

In this study, we explored the pharmacology of normal and learned responses measured directly in the ICX. The results demonstrate that, compared with normal responses, learned responses in the ICX are preferentially mediated by NMDA receptors, even for single ICX units. In addition, this pharmacological specialization of learned responses disappears after long periods of prism experience. Based on these observations, several models for NMDA receptor participation in experience-dependent plasticity in the ICX are discussed.

Parts of this paper have been published previously in abstract form (Feldman and Knudsen, 1995).

\section{MATERIALS AND METHODS}

Pharmacological measurements were made in one normal adult and eight prism-reared barn owls. Five additional normal owls were used in control experiments to assess ITD tuning along the 0 transect (defined below). All owls were also used in other studies (Feldman et al., 1996; Feldman and Knudsen, 1997).

Prism experience. Owls were reared with normal visual experience until $60-65 \mathrm{~d}$ of age. At this age, Fresnel prismatic lenses (40 diopters; VisionCare/3M, St. Paul, MN) mounted in lightweight aluminum spectacle frames were attached to the skull while birds were anesthetized with halothane $(2 \%)$ in a nitrous oxide/oxygen mixture (4:5) as described previously (Feldman and Knudsen, 1997). The prisms displaced a region of the visual field measuring $>45^{\circ}$ in azimuth and elevation, centered on the visual axes (Brainard and Knudsen, 1993). When owls were mature enough to fly (65-70 d of age), they were placed in large flight cages with other owls to maximize visual and auditory experience. Under these conditions, ITD tuning in the ICX and optic tectum begins to shift within $20 \mathrm{~d}$ of prism attachment (Feldman, 1997). Pharmacological measurements were made 25-400 d after prism attachment.

Electrophysiological recording. Owls were prepared for multiple electrophysiology experiments using methods described previously (Feldman and Knudsen, 1994). During recording sessions, owls were anesthetized with nitrous oxide/oxygen in the minimum ratio needed to maintain anesthesia (2:5-4:5). Pharmacological measurements were made under these conditions. Measurements were halted, and halothane $(1 \%$ in the nitrous oxide/oxygen mixture) was administered if the bird showed any signs of discomfort. No differences in pharmacology were apparent when measurements were made under nitrous oxide anesthesia versus in nonanesthetized, quiet birds [the method used by Feldman and Knudsen (1994) and Feldman et al. (1996)].

Recordings were made using five-barrel glass iontophoresis electrodes, the central recording barrel of which contained a carbon fiber $7 \mu \mathrm{m}$ in diameter (Feldman and Knudsen, 1994). Drug barrels had 1-2 $\mu \mathrm{m}$ tips and contained either the NMDA receptor antagonist D,L-2-amino-5phosphonopentanoic acid (AP-5; $67 \mathrm{mM}$ in $\mathrm{dH}_{2} 0$, adjusted to $\mathrm{pH} 7.4$ with $\mathrm{NaOH}$ ) or the non-NMDA receptor antagonist 6-cyano-7nitroquinoxaline-2,3-dione (CNQX; $10 \mathrm{~mm}$ in $\mathrm{dH}_{2} 0, \mathrm{pH}$ 8.9). Current balance was not used because iontophoresis of $\mathrm{pH}$-matched saline solutions had no effect on spontaneous firing or on auditory responses of IC neurons (Feldman and Knudsen, 1994). Retaining currents (3-15 nA) were routinely used on all drug barrels. Recordings were made at single or multiunit sites (2-5 units). Units were isolated with a slope-amplitude window discriminator (BAK Electronics, Rockville, MD).

Auditory responses were characterized as described previously (Feldman and Knudsen, 1994). Briefly, stimuli were generated digitally and presented dichotically at a level $20-30 \mathrm{~dB}$ above unit threshold. Unit tuning for ITD was determined by presenting 10-100 series of bandpassed $(4-12 \mathrm{kHz})$ noise bursts in which ITD was varied in a random, interleaved order. Responses were defined as the number of spikes in the $100 \mathrm{msec}$ after stimulus onset minus the number in the $100 \mathrm{msec}$ before stimulus onset. ITD tuning curves were described by their width, defined as the range of ITDs over which responses exceeded $50 \%$ of the maximum response, and the best ITD was the midpoint of this range. ITD tuning was measured with the interaural level difference held at its best value. 
Recordings were made in the ICX and ICCls. The relative locations of these nuclei in the optic lobe of the owl are shown in Figure $2 A$. Each recording site was assigned to one of these nuclei based on the neuronal tuning for ITD, interaural level difference, and frequency, as described previously (Brainard and Knudsen, 1993). ICCls units were narrowly tuned for frequency (median tuning width for units in a penetration, $<2.4$ $\mathrm{kHz}$ ), were sensitive to or tuned for interaural level difference, and responded equally well to ITD values separated by integer multiples of the period of the best frequency of the unit (Wagner et al., 1987). Best frequencies progressed from low to high values with dorsoventral depth in the ICCls. In contrast, ICX units had broad frequency tuning (median width in a penetration, $>2.5 \mathrm{kHz}$ ), and in dorsoventral penetrations, the best interaural level difference progressed from right ear greater to left ear greater values. ICX units were tuned to a single best value of ITD. These identifying physiological criteria have been confirmed by anatomical reconstruction of the recording sites in each nucleus (Brainard and Knudsen, 1993).

ICX transects. To identify normal and learned responses of ICX neurons, we used a technique developed by Brainard and Knudsen (1993) in which recordings are made along a physiologically defined transect that passes through the representation of a single ITD value in the ICCls, ICX, and optic tectum (Fig. 2A). The ICCls endpoint of each transect was the representation of a given ITD value in the ICCls, and the tectal endpoint was the representation in the superficial tectal layers of the visual azimuth that normally corresponds to that ITD, based on the regression of visual receptive field azimuth on the best ITD for normal adults (Brainard and Knudsen, 1993). Because of the mutual alignment of ITD maps across these nuclei in normal owls, each transect passes through the representation of the same ITD value in the ICX, ICCls, and tectum (Fig. $2 A$ ). Such iso-ITD transects were named for the ITD value represented along them in normal owls (e.g., the transect through the representations of $0 \mu \mathrm{sec}$ ITD was termed the 0 transect, and that through the representations of $20 \mu \mathrm{sec}$ contralateral ear leading ITD was termed the c20 transect). A given transect passes through the same anatomical locations in both normal and prism-reared owls, because prism rearing alters neither the representation of ITD in the ICCls nor the representation of visual azimuth in the tectum (Brainard and Knudsen, 1993; Feldman and Knudsen, 1997). However, because the representation of ITD in the ICX is altered by prism rearing, the ITD tuning of ICX and tectal units recorded along a given transect in prism-reared owls is shifted away from the tuning observed along the same transect in normal owls (Brainard and Knudsen, 1993; Feldman, 1997).

In this study, a series of dorsoventral penetrations was made along a given iso-ITD transect, and units recorded along the transect were classified as being within the ICX or the ICCls based on the physiological criteria presented above. Penetrations were separated by a nominal distance of $220-360 \mu \mathrm{m}$. The ICCls-ICX border was estimated as the point halfway between the most lateral ICCls penetration and the most medial ICX penetration on a given transect. A point on each transect 500 $\mu \mathrm{m}$ lateral of the ICCls-ICX border was used to subdivide the ICX into medial and lateral parts (the ICX measures $\sim 1 \mathrm{~mm}$ in width along the 0 transect).

Identification of transition state ITD tuning in the ICX. In prism-reared owls, ICX units with transition state ITD tuning were identified by recording along iso-ITD transects and by comparing unit ITD tuning with the tuning observed along the same transect in normal owls. This method is illustrated in Figure 2 for sites on the 0 transect. In normal owls, sites in the lateral half of the ICX on this transect had best ITD values near $0 \mu \mathrm{sec}$ (representative tuning curves are shown in Fig. 2B). For 90 units along 11 such transects in six normal owls, the mean best ITD observed at sites in the lateral half of the ICX was $3.0 \pm 5.7 \mu \mathrm{sec}$ $( \pm \mathrm{SD})$ contralateral ear leading ITD (Fig. 2B, inset).

Along this same transect in prism-reared owls, ITD tuning in the lateral half of the ICX was shifted in the adaptive direction determined by the direction of prismatic displacement. Early in prism rearing, after 20-60 d of prism experience, most units exhibited small shifts in ITD tuning away from the tuning observed in normal owls (Fig. 2C). Such tuning curves were classified as transition state tuning curves if (1) the best ITD was shifted in the adaptive direction by at least $9 \mu \mathrm{sec}$, which was the 95th percentile of the distribution of best ITDs in normal owls; and (2) normal responses, defined below, were present at a mean level of at least $20 \%$ of the maximum response of the unit. Examples of transition state tuning curves are shown in Figure $2 C$.

For each transition state tuning curve, a range of normal responses $(N M L)$ was defined as responses to ITDs within $10 \mu \mathrm{sec}$ of the normal best ITD for the transect. In addition, a range of learned responses $(L N D)$ was defined as responses to ITDs $40 \pm 10 \mu \mathrm{sec}$ in the adaptive direction from the normal best ITD. The $40 \mu \mathrm{sec}$ value was chosen because it was close to the mean best ITD value of $36 \mu \mathrm{sec}$ observed in the lateral ICX after long periods of prism rearing (Feldman and Knudsen, 1997). However, some transition state tuning curves were narrow and did not contain consistent responses to ITDs $50 \mu \mathrm{sec}$ from transect normal (Fig. $2 C$, squares). For such curves, the learned response range was defined as $30 \pm 10 \mu \mathrm{sec}$ from the normal best ITD for the transect. After $>60 \mathrm{~d}$ of prism experience, most ITD tuning curves were dominated by learned responses (Fig. $2 D$ ). However, many sites still expressed normal responses at levels $>20 \%$ of the maximal response and thus were classified as transition state tuning curves.

The great majority of recordings in this study were made on the 0 transect. For units on other transects, the same criteria were applied. For each recording site, the normal best ITD for the transect was used as the estimate for the normal best ITD of the site, and normal and learned response ranges were defined relative to this normal best ITD value.

Iontophoresis protocol. At each recording site, ITD tuning was first assessed without drug ejection (control condition) using four to six presentations of a 10 repetition stimulus series in which ITD varied randomly across a range of values sampled at $10 \mu \mathrm{sec}$ intervals. AP-5 or CNQX was then applied iontophoretically at a current level that blocked auditory responses by $30-70 \%$ (see below). Once stable blockade was attained ( $\sim 2$ min after current onset), ITD tuning was remeasured using 4-10 presentations of the same 10 repetition stimulus series. At many sites, the ejection current was then increased to a new level, and ITD tuning was reassessed after responses stabilized. Finally, drug ejection was halted, responses were allowed to recover for a period of time equal to the period of drug application, and ITD tuning was reassessed. At least $70 \%$ recovery of control responses was required, or the data were discarded. When possible, the entire procedure was repeated using a different antagonist or different ejection currents. The effects of AP-5 and CNQX on ITD tuning were determined by comparing the average ITD tuning curves collected during control and recovery periods with those collected during periods of drug iontophoresis.

The goal of this study was to look for pharmacological differences between normal and learned responses within the transition state ITD tuning curve. To maximize the likelihood of observing such differences, we chose ejection currents for each site to produce a 30-70\% reduction of control auditory responses, measured across all ITDs. The ejection currents that produced such reductions ranged from 2 to $40 \mathrm{nA}$ for both AP-5 and CNQX. For AP-5, these current levels were shown previously to block NMDA receptors selectively relative to non-NMDA receptors in the ICX (Feldman and Knudsen, 1994). For CNQX, specificity for non-NMDA receptors was tested at a number of sites by measuring antagonism of ICX responses to iontophoresed quisqualic acid (QA; 20 $\mathrm{mM}$ in $\left.\mathrm{dH}_{2} \mathrm{O}, \mathrm{pH} 7.0\right)$, which is an agonist of the AMPA-type nonNMDA receptor, and to iontophoresed NMDA $\left(50 \mathrm{~mm}\right.$ in $\mathrm{dH}_{2} \mathrm{O}, \mathrm{pH}$ 4.5 ), which is an agonist of the NMDA receptor [for methods, see Feldman and Knudsen (1994)]. At some sites, CNQX produced a specific blockade of QA responses; however, at an equal number of sites, CNQX blocked both QA- and NMDA-evoked responses equally, even at low current levels $(5 \mathrm{nA})$. Such nonspecific action of CNQX on a subset of cells has been observed in other iontophoretic studies (Salt and Eaton, 1989; Salt et al., 1995) and may reflect a direct blockade of non-NMDA receptors together with an indirect reduction of NMDA receptor currents by virtue of their voltage sensitivity (Nicoll et al., 1990). Because of this heterogeneity of CNQX effects, it would have been preferable to test the specificity of CNQX on each ICX neuron for which the pharmacology of auditory responses was measured. It proved impossible, however, to hold units long enough in these lightly anesthetized birds to measure both auditory and agonist responses at each site. Therefore, in interpreting these results, it should be assumed that CNQX reduced NMDA and non-NMDA (AMPA) receptor currents relatively nonselectively.

Analysis of drug effects on ITD tuning curves. Drug effects were quantified by calculating separately for each ITD value in the tuning curve the percent of control response remaining during drug application. The mean percent response remaining for different ranges of ITDs was then compared. For transition state ITD tuning curves, these ranges were the normal and learned response ranges defined above. For tuning curves in which learned responses were not present (i.e., tuning curves in normal owls and tuning curves in the ICCls of prism-reared owls), ranges that were symmetrically opposed on the two flanks of the tuning curve were used. In these cases, each range consisted of ITDs $20 \pm 10 \mu \mathrm{sec}$ from the 

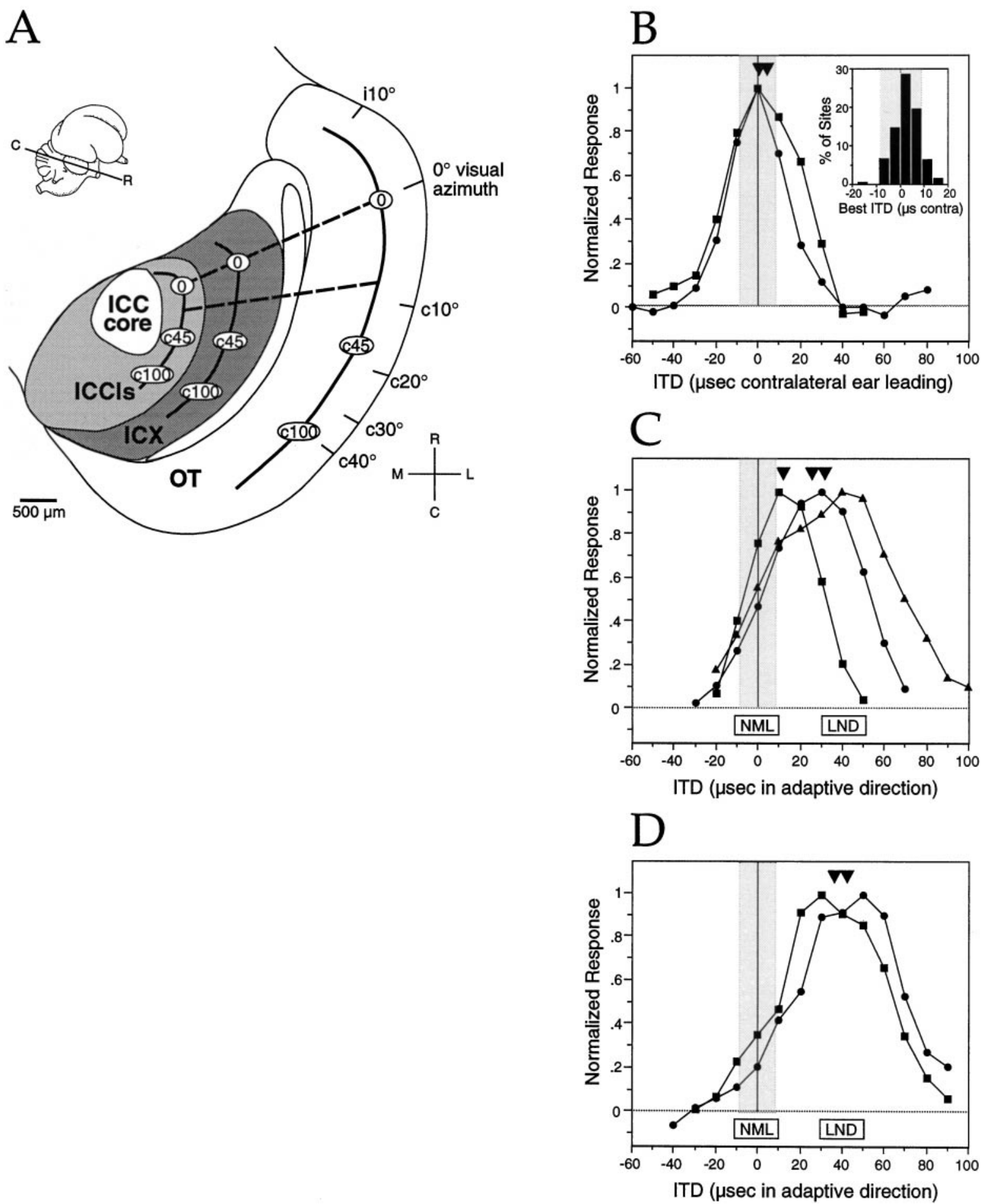

Figure 2. Method for identification of transition state ITD tuning in the ICX. A, Iso-ITD transects (dashed lines) superimposed on the maps of ITD in the ICCls, ICX, and optic tectum in a schematic horizontal section through the optic lobe of a normal owl. Ovals denote locations of neurons tuned to 0, 45, and $100 \mu \mathrm{sec}$ contralateral ear leading ITD in each nucleus, based on previous mapping studies (Brainard and Knudsen, 1993; Feldman and Knudsen, 1997). Dark lines indicate axes of varying best ITD in each nucleus. The map of visual azimuth in the tectum is also indicated. $c$, Contralateral; $i$, ipsilateral; $O T$, optic tectum. $B$, Representative ITD tuning curves from sites in the lateral half of the ICX on the 0 transect in a juvenile (circles) and a normal adult (squares) owl. Triangles indicate best ITDs. Inset, Distribution of best ITD values measured in the lateral ICX on the 0 transect for 90 sites in six normal owls. Ninety-five percent of all units had best ITDs within \pm 9 of $0 \mu \mathrm{sec}$ (indicated by the gray region in all panels). $C$, Three representative transition state ITD tuning curves (square, circle, and small triangle) recorded in the lateral half of the ICX on the 0 transect in owls with 20-60 d of prism experience. Best ITDs (large triangles) are shifted in the adaptive direction determined by the direction of the prismatic displacement: toward left ear leading ITD values in owls wearing R23 $3^{\circ}$ prisms and toward right ear leading ITD values in owls wearing L23 ${ }^{\circ}$ prisms. For all figures in this paper, the ITD axis has been adjusted so that the adaptive direction is toward the right side of the page. $N M L$ and $L N D$, Normal and learned ranges of ITDs for transition state tuning curves, defined in Materials and Methods. $D$, Typical ITD tuning curves recorded after $>60 \mathrm{~d}$ of prism experience. 

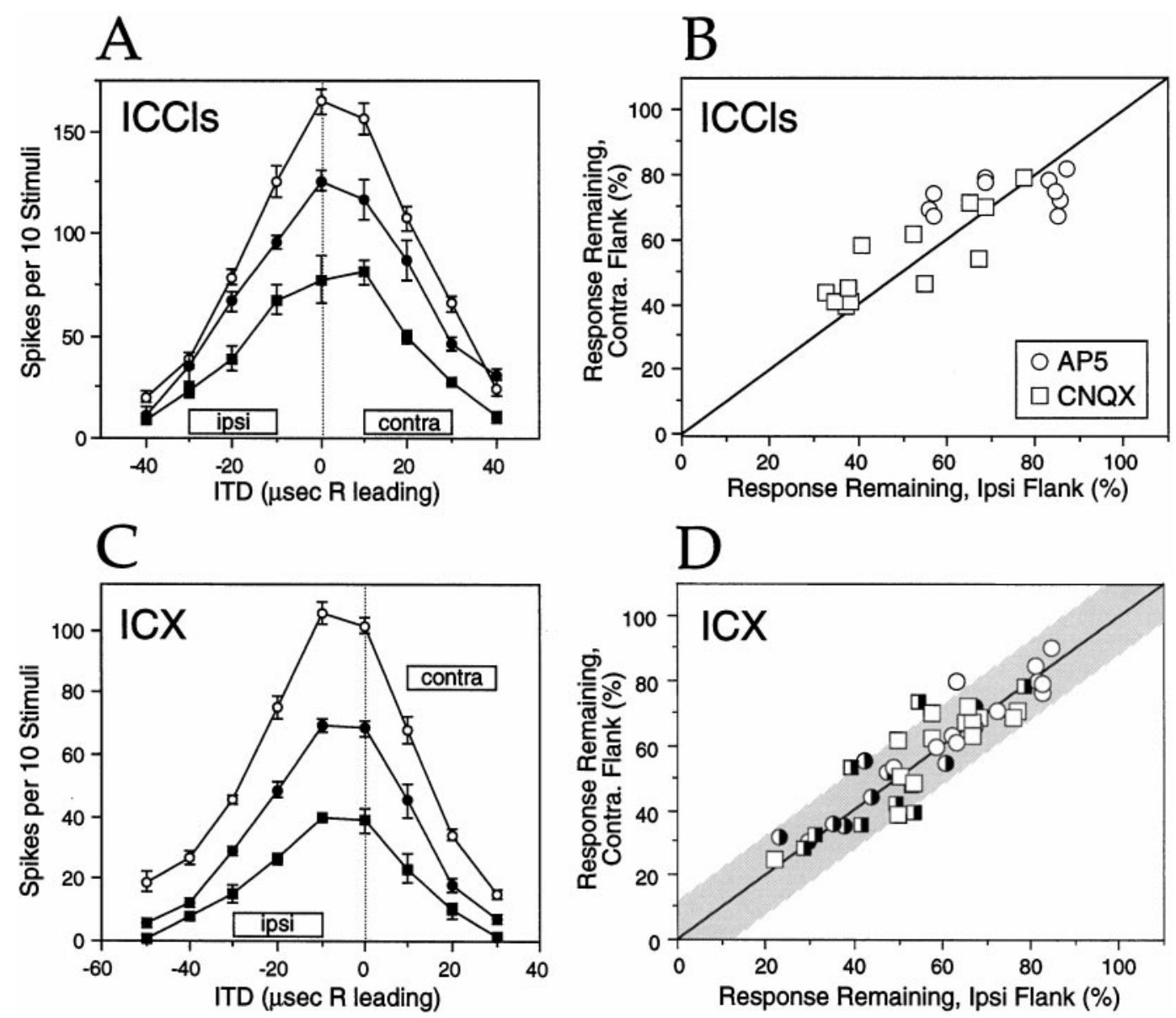

Figure 3. Effects of AP-5 and CNQX on ITD tuning in the ICCls and ICX of normal adult owls. $A$, ITD tuning at a representative ICCls site during control and recovery periods (open circles) and during periods of AP-5 ( filled circles; $25 \mathrm{nA}$ ) and CNQX (squares; $5 \mathrm{nA}$ ) iontophoresis. Error bars indicate SEM across multiple 10 repetition tuning curves collected during the different periods. Vertical line, Best ITD; boxes, ITD ranges used to quantify blockade on ipsilateral and contralateral ear leading flanks of the tuning curve. $B$, Symmetry of drug effects for all ICCls units. Circles, AP-5 ( $n=10$ units all $25 \mathrm{nA}$ ); squares, CNQX ( $n=11$ units; 5-25 nA). The diagonal line denotes equal blockade of both flanks. $C$, Effects of AP-5 ( filled circles; $40 \mathrm{nA}$ ) and CNQX (squares; $15 \mathrm{nA}$ ) at a representative site in the lateral half of the ICX. Vertical line, The predicted best ITD for the transect. $D$, Symmetry of drug effects for all ICX units. Open symbols, Lateral half of ICX; half-filled symbols, medial half; circles, AP-5 ( $n=25$ units; $10-40$ nA); squares, CNQX $(n=18$ units; $5-40 \mathrm{nA})$. The gray region indicates the normal range of blockade asymmetry produced by AP-5, calculated as the mean \pm 2 SD of the difference between blockade of contralateral and ipsilateral ear leading flanks of the tuning curve for all ICX units.

best ITD for the transect (for sites in the ICX) or from the best ITD of the tuning curve (sites in the ICCls).

To determine whether drug application blocked responses asymmetrically across the ITD tuning curve, we performed a least-squares linear regression on the relationship between ITD and the percent response remaining during drug application. This analysis was restricted to ITDs for which control responses were $>15 \%$ of the maximum response for the site. If the regression had a significant nonzero slope $(p<0.05)$, the site was classified as exhibiting an asymmetric blockade across the ITD tuning curve.

\section{RESULTS}

\section{The ICCls and ICX of normal adult owls}

To establish the sensitivity and reliability of our pharmacological technique, we measured the pharmacology of auditory responses of ICX and ICCls units in normal adult owls. In both nuclei, auditory responses displayed uniform glutamatergic pharmacology across the ITD tuning curve. In the ICCls, NMDA receptorspecific levels of AP-5 were applied at 12 multiunit sites, and in each case responses on both flanks of the tuning curve were blocked equally. CNQX, applied at the same sites, produced the same result. Data from a representative site are shown in Figure
$3 A$. The mean ITD tuning curve observed during control and recovery periods (open circles) was reduced symmetrically during application of AP-5 ( filled circles) and CNQX (squares). Blockade was quantified for a range of ITDs on the ipsilateral ear leading flank of the tuning curve (ipsi) and for a corresponding range on the contralateral ear leading flank (contra). Across all ICCls sites tested, there was no difference in the amount of blockade observed for these ITD ranges, for either AP-5 or CNQX (Fig. 3B). The small magnitude of response blockade observed with AP-5 at these sites (Fig. 3B, circles) is consistent with a previous study showing that NMDA receptors mediate a small proportion of the auditory response in the ICCls (Feldman and Knudsen, 1994).

Similar results were obtained in the ICX. Both AP-5 $(n=26$ sites) and CNQX ( $n=17$ sites) reduced responses uniformly across ITD tuning curves, as illustrated for a representative site in Figure $3 C$. Results from the entire population of ICX sites are shown in Figure 3D. Equal blockade on the two flanks of the tuning curve was apparent both in the lateral (open symbols) and medial (half-filled symbols) halves of the ICX and over a large range of overall response reduction (indicated by the distance 

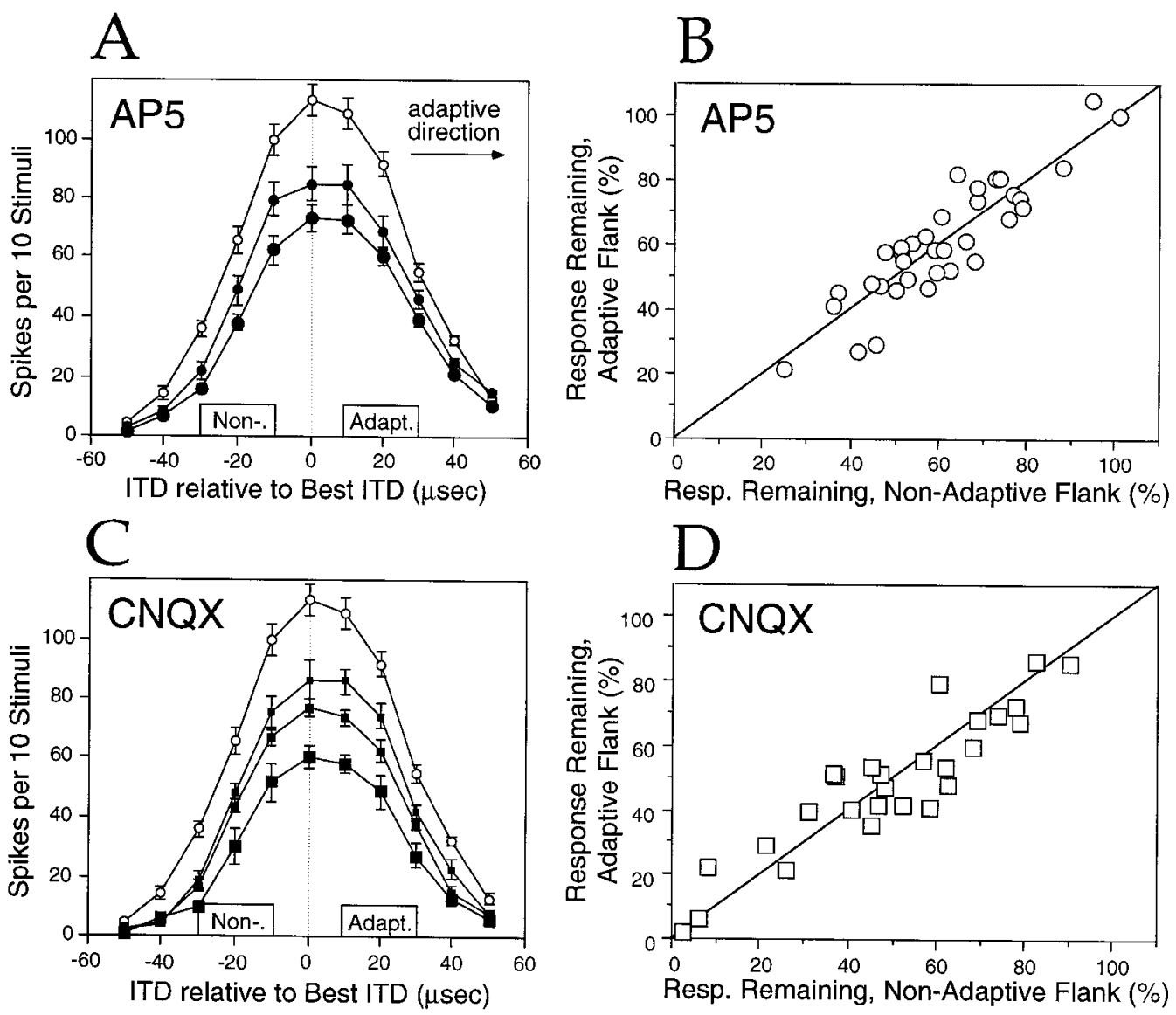

Figure 4. Effects of AP-5 and CNQX on ITD tuning in the ICCls of prism-reared owls. A, Effects of AP-5 at a representative site. Open circles, Mean responses during control and recovery periods; large and small filled circles, mean responses during application of 10 and $25 \mathrm{nA}$ AP-5, respectively; arrow, direction of ITD tuning modification observed in the ICX of the same owl; boxes, ITD ranges for quantification of blockade on the adaptive (Adapt) and nonadaptive (Non-) flanks of the tuning curve. B, Blockade of responses by AP-5 on nonadaptive versus adaptive flanks of the tuning curve for all ICCls sites tested. Each point corresponds to the application of one ejection current, of which there were more than one for some sites. Range of ejection currents, 2-40 nA. C, Effects of CNQX at the same site shown in A. Increasing square sizes, 20, 25, and $35 \mathrm{nA}$ CNQX, respectively. $D$, Effects of CNQX at all sites tested. Range of ejection currents, 7-40 nA.

from the origin in Fig. 3D). The mean difference in response blockade between contralateral and ipsilateral ear leading flanks was only $1.2 \pm 6.3 \%( \pm \mathrm{SD})$ for AP-5 applications and $1.8 \pm 8.4 \%$ for CNQX applications.

\section{The ICCls of prism-reared owls}

The results presented above indicated that in normal owls, the glutamatergic pharmacology of auditory responses is uniform across the ITD tuning curve. We next examined auditory responses in the ICCls of prism-reared owls. It has been shown previously that although ITD tuning shifts in the ICX of prismreared owls, ITD tuning modification does not occur in the ICCls (Brainard and Knudsen, 1993; Feldman and Knudsen, 1997).

AP-5 $(n=29$ sites) and CNQX ( $n=22$ sites) were applied at ICCls sites in prism-reared owls after 29-154 d of prism experience. At several sites, multiple doses of these drugs were applied. It was verified in these owls that shifted-ITD tuning was present in the ICX, just a few hundred micrometers away from the ICCls sites. We found that both AP-5 and CNQX reduced responses uniformly across the ITD tuning curve of these ICCls units (Fig. $4 A, C)$. This effect was quantified by comparing the blockade of responses for a range of ITDs on the flank of the tuning curve corresponding to the direction of ITD tuning shift in the ICX (the "adaptive" direction) versus the blockade for a symmetrically opposed ITD range on the other flank (the "nonadaptive" direction). Across all sites, equal blockade on both flanks of the tuning curve was observed for both AP-5 (Fig. 4B) and CNQX (Fig. $4 D$ ). Together, these results and those obtained in normal owls (Fig. 3) indicate that the glutamatergic pharmacology of auditory responses is uniform across the ITD tuning curve for ICX and ICCls sites that have not undergone ITD tuning modification.

\section{Effect of AP-5 on transition state ITD tuning in the ICX of prism-reared owls}

A very different pharmacological profile was observed for ICX units with ITD tuning that had been modified by prism rearing. In prism-reared owls, transition state ITD tuning, as defined in Materials and Methods and Figure 2, was observed at many sites in the lateral half of the ICX. These sites were recorded on iso-ITD transects (see Materials and Methods) and expressed normal responses to a range of ITDs centered around the normal best ITD for the transect, as well as learned responses displaced from transect normal in the adaptive direction. When AP-5 was applied at such sites, a nonuniform reduction of responses across the ITD tuning curve was often observed (Fig. 5). Figure $5 A$ shows the results of AP-5 application at one such multiunit site. 


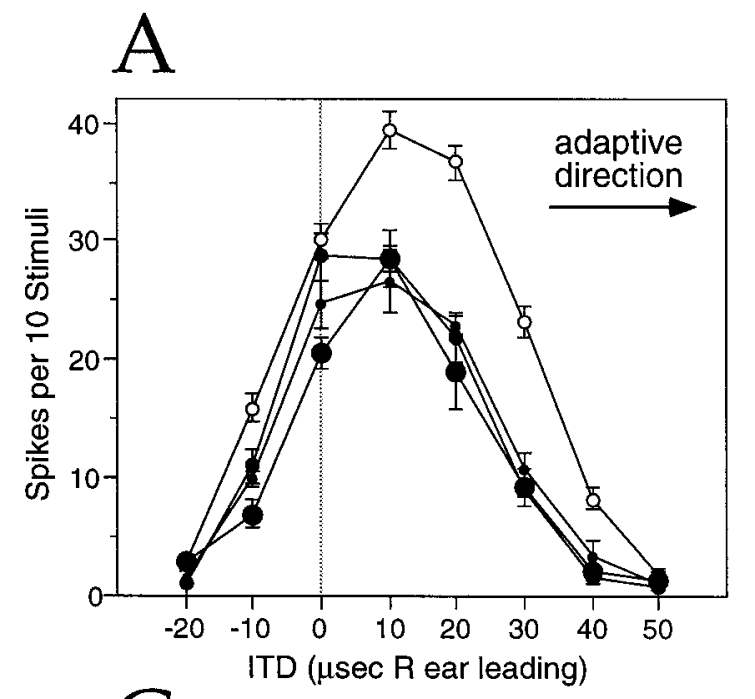

\section{B}
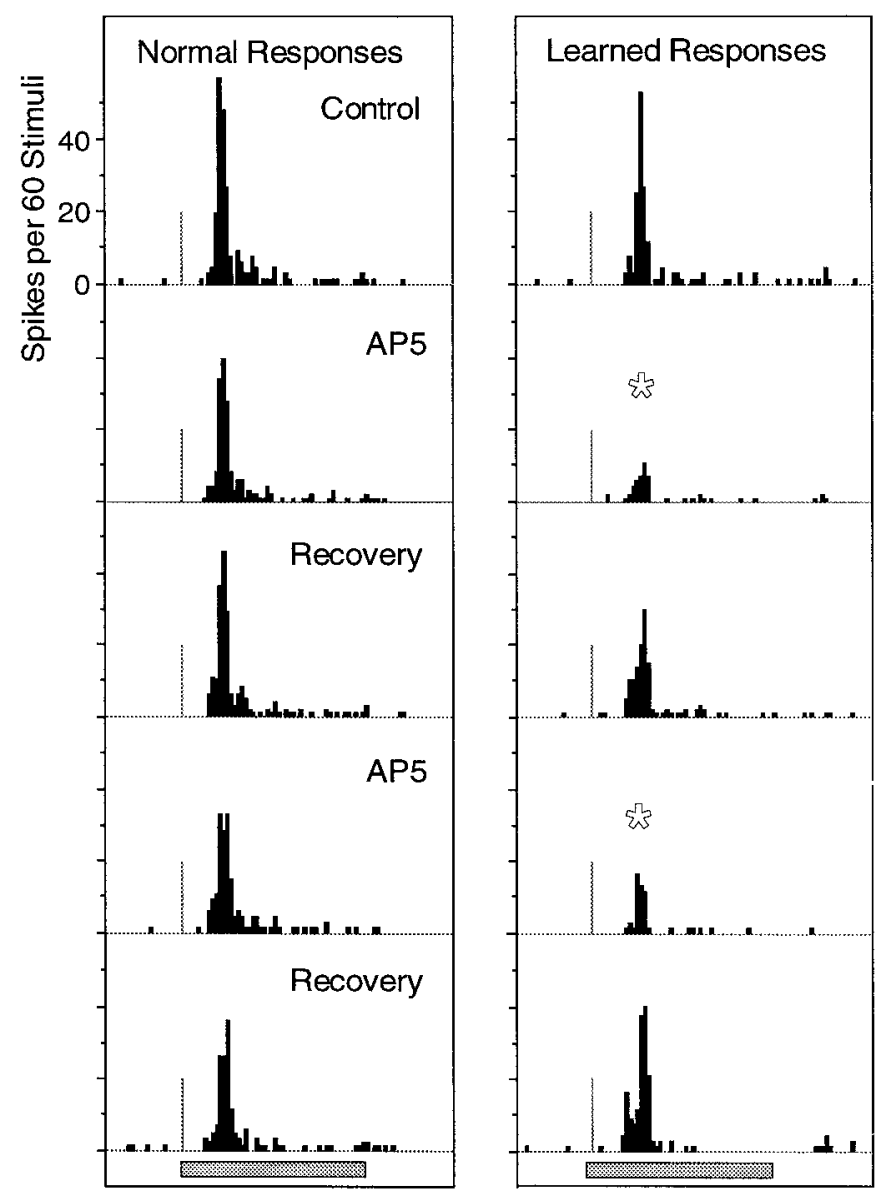

Figure 5. Effects of AP-5 on transition state ITD tuning in the ICX. A, Effect of AP-5 at a representative multiunit site. Vertical line, Normal best ITD for the transect. Best ITD under control conditions was shifted $13 \mu \mathrm{sec}$ from transect normal. Open circles, Tuning during control and recovery periods; closed circles, tuning during AP-5 applications (increasing closed circle size, 10, 25, and $40 \mathrm{nA}$, respectively); arrow, direction of ITD tuning modification. $B$, PSTHs for responses measured at the site in $A$ to stimuli of $0 \mu \mathrm{sec}$ (Normal) and $30 \mu \mathrm{sec}$ right ear leading (Learned) ITD. Asterisks denote blockade of learned responses. Vertical lines indicate the onset of the $50 \mathrm{msec}$ noise bursts (horizontal gray bars). C, Effects of AP-5 for different ejection currents (increasing closed circle size: 10, 20, and $40 \mathrm{nA}$, respectively) at another multiunit site. The asymmetric effect of AP-5 was apparent at all levels of response blockade.

Under control conditions (open circles; this includes both control and recovery periods), ITD tuning was shifted from normal for the transect $(0 \mu \mathrm{sec})$ in the adaptive direction predicted by the prismatic displacement (arrow). During periods of AP-5 application, responses to ITDs on the learned flank of the tuning curve were preferentially suppressed relative to responses on the normal flank of the curve. The same effect was observed during each of three separate applications of AP-5 (filled circles).

The preferential blockade of learned responses and recovery between AP-5 applications are shown for this site in peristimulus time histogram (PSTH) format (Fig. 5B). PSTHs for responses to 60 stimuli presented at $0 \mu \mathrm{sec}$ ITD (Normal Responses) and at 30 $\mu \mathrm{sec}$ right ear leading ITD (Learned Responses) are shown for a subset of the control, AP-5 application, and recovery periods used to construct the tuning curves in Figure $5 A$. Under control conditions, robust responses were observed to both stimuli, which were identical except for their ITD. During AP-5 application, learned responses were preferentially and reversibly reduced (asterisks).

Another example of the asymmetric effect of AP-5 on transition state ITD tuning is shown in Figure $5 C$. Three different ejection currents of AP-5 were applied, producing increasing levels of overall response blockade. Preferential blockade of responses on the learned flank of the ITD tuning curve was observed for all current levels.

\section{Quantification of the effect of AP-5 on transition state ITD tuning}

To quantify the effects of AP-5 on transition state ITD tuning curves, we calculated the percent of control response remaining during AP-5 application for each ITD tested at a given site (Fig. $6 A, B$, bottom panels). A significant linear regression between percent response remaining and ITD was taken to indicate a significant asymmetry in the effect of AP-5 across the tuning 

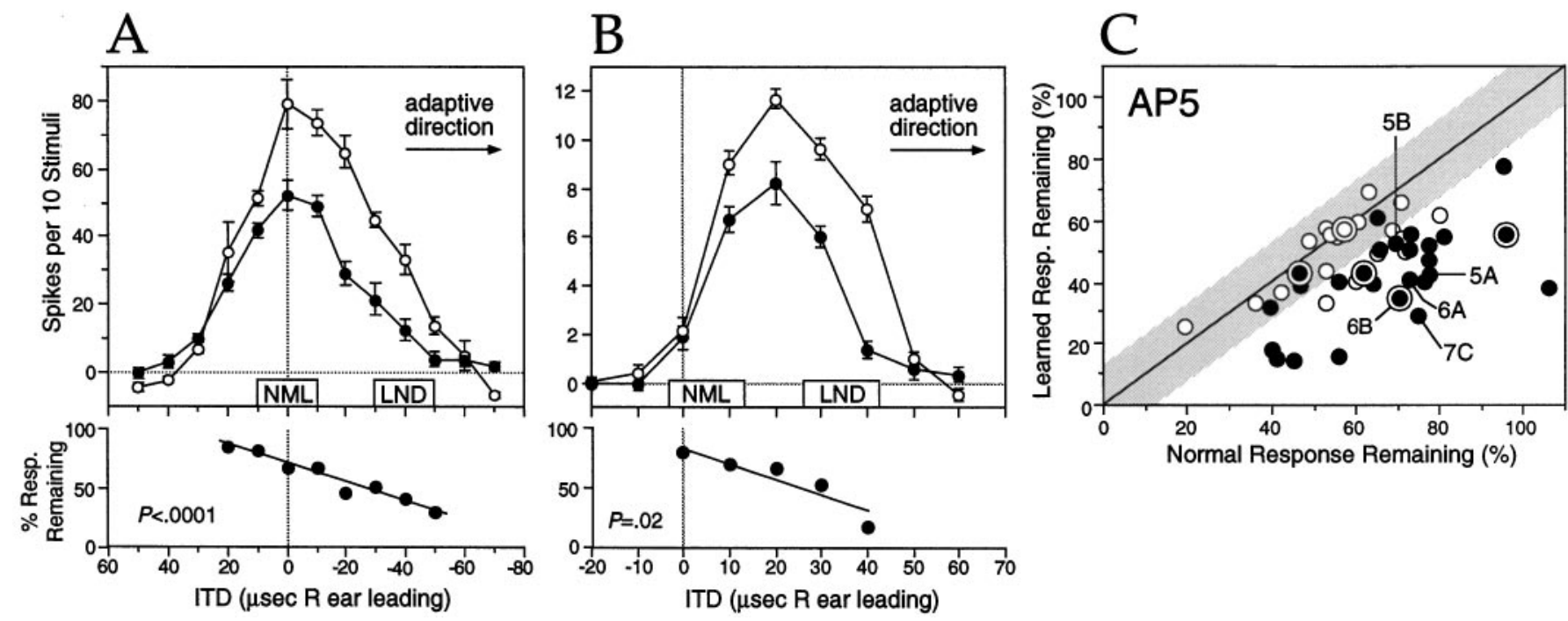

Figure 6. Quantification of the effect of AP-5 on transition state ITD tuning in the ICX. All units are from owls with 30-154 d of prism experience. $A$, Effect of AP-5 (32 nA) at a representative multiunit site. Vertical line, Normal best ITD for the transect; boxes, ITD ranges for quantification of normal $(N M L)$ and learned $(L N D)$ responses. Bottom panel, Percent control response remaining during AP-5 application for ITDs with control responses $>15 \%$ of maximum; line, linear regression $\left(R^{2}=0.95 ; p<0.0001\right)$. $B$, Similar effect at a representative single-unit site $(25 \mathrm{nA}$ AP-5). Line, Linear regression $\left(R^{2}=0.77 ; p<0.02\right)$. At this site, the normal response range was defined as $0-10 \mu$ sec right ear leading ITD because significant control responses to $10 \mu \mathrm{sec}$ left ear leading ITD were not present. $C$, Effect of AP-5 on normal and learned responses for all sites in the lateral half of the ICX with transition state ITD tuning (range of ejection currents, 6-40 nA). The diagonal indicates equal blockade of normal and learned responses. Filled circles, Sites with significant asymmetric effects of AP-5 by the linear regression test; concentric circles, single units; gray region, normal range of asymmetry observed with AP-5 in the ICX of normal owls (from Fig. 3D). For sites at which multiple AP-5 current levels were tested (Fig. 5C), results of the median current application were used for this analysis. Points corresponding to selected figure panels are indicated.

curve. Two examples of asymmetric effects of AP-5 are shown (Fig. 6A, a multiunit site, $B$, a well-isolated single unit). In addition, the sites in Figures 5, $A$ and $C$, and $7 C$ all exhibited significant asymmetries in the effect of AP-5.

The response blockade produced by AP-5 for normal and learned ITD ranges was compared for each site with transition state ITD tuning (Fig. 6C). All sites were located in the lateral half of the ICX. Of 41 different ICX sites with transition state ITD tuning recorded in owls with 30-154 d of prism experience, AP-5 blocked learned responses more than normal responses at 33 sites (80\%; points below the diagonal). Of these, 24 (59\% of the total population) showed statistically significant asymmetric effects of AP- 5 by the linear regression test ( filled circles). At no site were normal responses blocked significantly more than learned responses. Asymmetric blockade by AP-5 was not an artifact of multiunit recording, because four out of five single units tested (Fig. 6B) also showed significant asymmetric response blockade with AP-5 (Fig. 6C, concentric circles). The binomial probability for observing 24 significant effects out of a population of 41 sites was calculated to be $p=3.8 \times 10^{-21}$, indicating that the prevalence of asymmetric effects of AP-5 was highly unlikely to have occurred by chance.

To show that the asymmetric effect of AP-5 was related to a differential blockade of learned versus normal responses rather than to other factors that may vary across transition state ITD tuning curves, we performed the analyses shown in Figure 7. First, we confirmed that for sites with significant asymmetric effects of AP-5, response blockade increased with increasing ITD in the adaptive direction, as opposed to absolute left or right ear leading ITD (Fig. 7A). Second, we determined that differential response blockade was independent of absolute ipsilateral or contralateral ear leading ITD. Of the sites shown in Figure $7 A$, seven had learned responses on the contralateral ear leading flank of the ITD tuning curve, whereas 17 had learned responses on the ipsilateral ear leading flank, yet all showed increased blockade with increasing ITD in the adaptive direction. Third, for these same sites, there was no correlation between response blockade and magnitude of the original control response (Fig. 7B). Fourth, we also eliminated the hypothesis that, because most of our sites were located on the 0 transect, AP-5 might preferentially block responses to non- $0 \mu \mathrm{sec}$ ITDs rather than to learned ITDs per se. To do this, we recorded from several sites on the $\mathrm{c} 30$ transect at which ITD tuning was shifted toward $0 \mu \mathrm{sec}$ ITD. At these sites, AP-5 preferentially reduced the responses to $0 \mu$ sec ITD, which were the learned responses for these sites (Fig. 7C).

In a final control, we identified seven sites in the lateral half of the ICX in prism-reared owls at which ITD had not been shifted by prism rearing (i.e., best ITD was shifted by $<9 \mu$ sec from normal for the transect; see Materials and Methods). AP-5 was applied at each of these unshifted sites, and in no case was a significant asymmetric effect of AP-5 observed (Fig. 7D,E). Together, these data indicate that the asymmetric response blockade produced by AP-5 at ICX sites with transition state ITD tuning is likely to reflect differential blockade of learned responses acquired as a consequence of prism experience.

\section{Effect of CNQX on transition state ITD tuning in the ICX of prism-reared owls}

In principle, the preferential blockade of learned responses by AP-5 could reflect either a pharmacological difference between normal and learned responses or a difference in the accessibility of iontophoresed antagonists to synapses mediating the two response types. To distinguish between these possibilities, we applied CNQX at sites with transition state ITD tuning using the same protocol used for AP-5. CNQX and AP-5 were applied at many of the same sites, with periods of CNQX and AP-5 appli- 

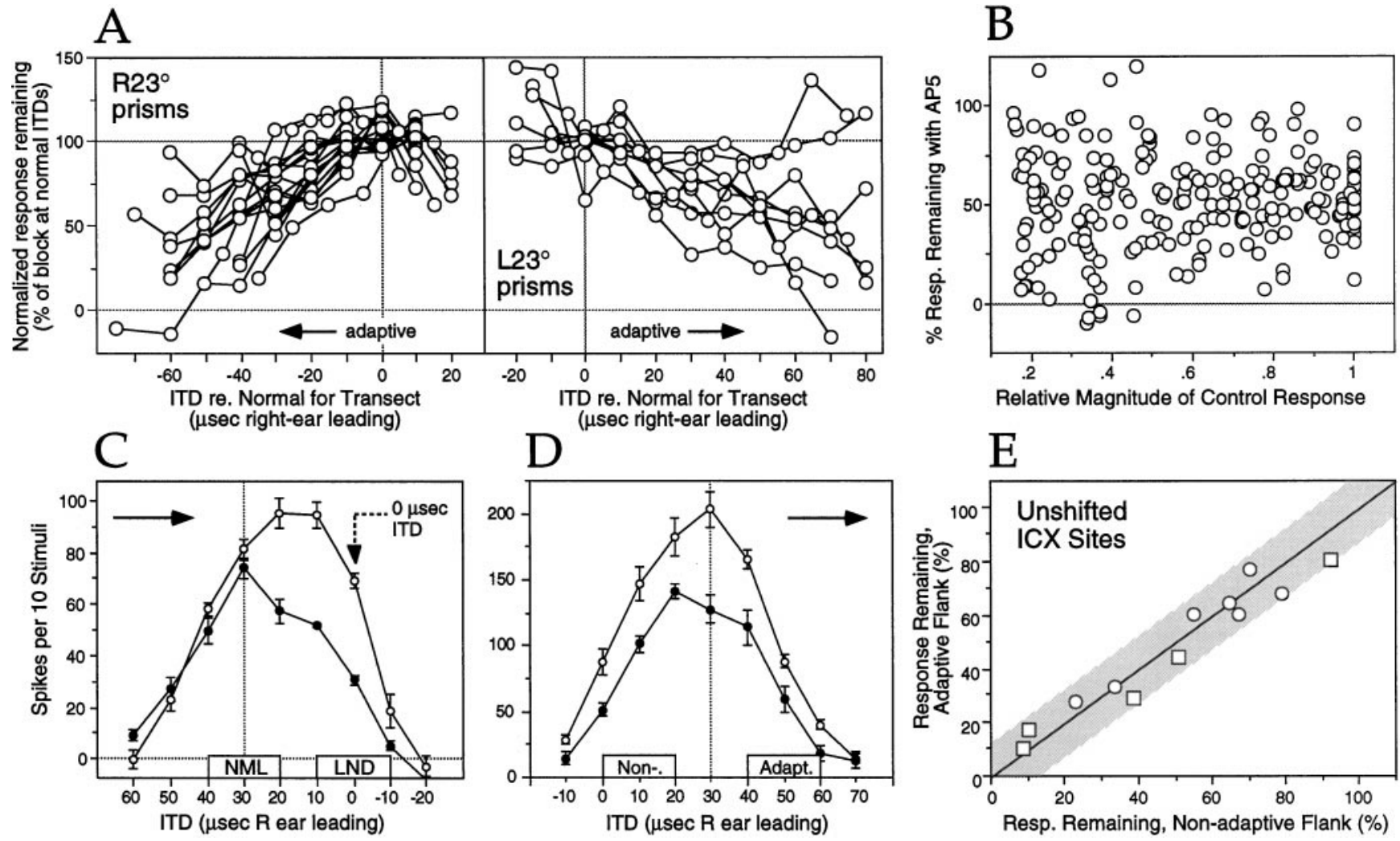

Figure 7. Correlation of response blockade by AP-5 with ITD in the adaptive direction, demonstrating a preferential blockade of learned responses. $A$, Relationship between response blockade by AP-5 (normalized to the mean blockade for normal responses at each site) and ITD relative to transect normal for all sites at which response blockade by AP-5 was significantly asymmetric. On the $y$-axis, 0 indicates complete response blockade. On the left are sites from owls wearing R23 $3^{\circ}$ prisms, for which learned responses are to ITD values that are more left ear leading than normal (i.e., the adaptive direction is left ear leading). On the right are sites from owls wearing L $23^{\circ}$ prisms, for which the adaptive direction is toward right ear leading ITDs. AP-5 sensitivity increases with ITD in the adaptive direction in both cases. $B$, Lack of correlation of the magnitude of response blockade by AP-5 with the magnitude of control responses for the same sites shown in $A$. Response magnitude is normalized to the maximum response observed within the control tuning curve of each site. $C$, Example of preferential blockade of learned responses by AP-5 (10 nA) when learned responses were at $0 \mu$ sec ITD. Horizontal arrow shows the adaptive direction. $D$, Example of the uniform effect of AP-5 (15 nA) at an unshifted site in the lateral half of the ICX in a prism-reared owl (93 d of prism experience). Arrow shows the adaptive direction. E, Effects of AP-5 (circles; 15-25 nA) and CNQX (squares; all 25 $\mathrm{nA})$ on adaptive and nonadaptive flanks of unshifted tuning curves $(n=7$ lateral ICX sites; all $<175 \mathrm{~d}$ of prism experience). Gray region, Normal range of blockade asymmetry observed with AP-5 in normal owls.

cation interleaved. Unlike AP-5, CNQX blocked responses uniformly across the ITD tuning curve, and a qualitative difference in the effects of AP-5 and CNQX was typically observed at single sites (Fig. 8A,B).

CNQX was applied at 19 sites with transition state ITD tuning. For each site, response blockade was compared for normal and learned response ranges (Fig. 8C), and a linear regression was performed to detect significantly asymmetric effects of CNQX (Fig. 8A,B, bottom panels). At no site did CNQX mimic the effect of AP-5. Instead, CNQX blocked normal and learned responses equally, within the range of variability observed in normal adults (Fig. 8C, gray zone). At only one site was a significant asymmetry in blockade observed (black square), and the direction of asymmetry at that site was opposite to that observed with AP-5. Importantly, equal blockade of normal and learned responses by CNQX was observed at every site that displayed an asymmetric effect of AP-5 ( $n=10$ sites; squares with $X)$. In addition, equal blockade of normal and learned responses was observed over a large range of overall response blockade by CNQX (Fig. 8A,C), the same range over which AP-5 produced its asymmetric effect (Fig. 6C). This indicates that the different effects of AP-5 and
CNQX cannot be attributed to differences in the overall amount of blockade produced by these two agents.

\section{Pharmacology of fully shifted ITD tuning curves}

The pharmacological difference between normal and learned responses, described above, disappeared after lengthy periods of prism experience. Although transition state ITD tuning curves were rare in the ICX after $\sim 160 \mathrm{~d}$ of age, most sites retained a low level of normal responses, and occasionally sites with strong normal responses were found. To characterize the pharmacology of normal and learned responses after a complete ITD tuning shift, we sought ICX sites with residual normal responses $>20 \%$ of the maximal response in owls after very long periods of prism experience ( $>235 \mathrm{~d}$ of age or $>175 \mathrm{~d}$ of prism experience). AP- 5 was applied at these sites, and the effects were characterized using the same methods that were used for units in younger owls.

In contrast to the effects observed in younger owls, AP-5 no longer blocked learned responses preferentially after $235 \mathrm{~d}$ of age. Instead, AP-5 blocked responses uniformly across the ITD tuning curve (Fig. 9). A site with ITD tuning typical of that observed after $235 \mathrm{~d}$ of age is shown in Figure $9 A$. There was no significant 

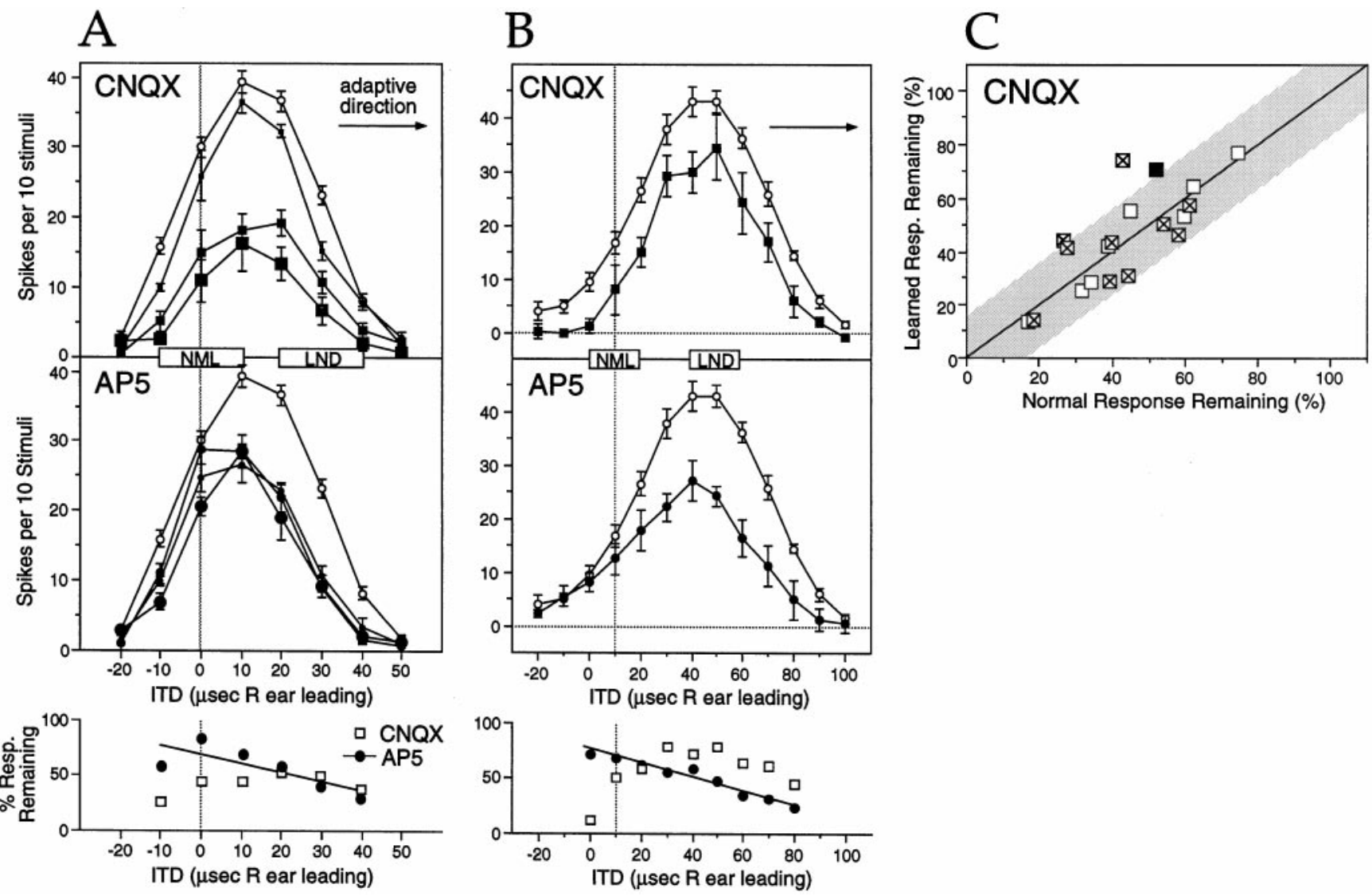

Figure 8. Effect of CNQX on transition state ITD tuning in the ICX. The units were from owls with 30-154 d of prism experience. A, Effect of increasing ejection currents of CNQX (increasing square size, 4, 5, and $10 \mathrm{nA}$, respectively) at a representative site. Vertical line, Normal best ITD for the transect. The effect of AP-5 (increasing closed circle size, 10, 25, and $40 \mathrm{nA}$, respectively) at this same site is shown below for comparison (same site shown in Fig. 5A). Bottom panel, Blockade produced by the median ejection currents of CNQX (squares) and AP-5 (circles and regression line) as a function of ITD. AP-5, $R^{2}=0.705$ and $p=0.0008$; CNQX, no significant regression $(p=0.80)$. $B$, Another example. Vertical line, Normal ITD for the transect $(\mathrm{R} 10 \mu \mathrm{sec})$. AP-5, $R^{2}=0.946$ and $p<0.0001$; CNQX, no significant regression $(p=0.37)$. $C$, Response blockade produced by CNQX for normal and learned responses for all sites with transition state ITD tuning. Gray region, Normal range of blockade asymmetry observed with CNQX in normal owls, calculated as the mean $\pm 2 \mathrm{SD}$ of the difference between the response blockade on the two flanks of the ITD tuning curve (from CNQX data in Fig. $3 D$ ); squares with $X$, sites showing significant AP-5 asymmetry; filled square, the single asymmetric effect of CNQX.

regression of the percent of control response remaining during AP-5 iontophoresis on ITD. Even at the few sites where robust normal responses remained, AP-5 blocked responses uniformly across the ITD tuning curve (Fig. 9B). None of the 21 sites tested after $235 \mathrm{~d}$ of age showed any evidence of a preferential blockade of learned responses by AP-5 (Fig. 9C).

This loss of pharmacological asymmetry after $235 \mathrm{~d}$ of age was also documented for one recording site using the technique used in the previous study, applying AP-5 in the ICX and recording auditory responses downstream in the optic tectum [for details of this method, see Feldman et al. (1996)]. The visual receptive fields measured at tectal sites provide an independent and precise indicator of normal and learned ITD ranges. A site in the tectum with robust transition state ITD tuning was found in a prismreared owl at $336 \mathrm{~d}$ of age ( $274 \mathrm{~d}$ of prism experience). Although it is extremely rare to find transition state ITD tuning in the tectum after this amount of prism experience, this site clearly exhibited transition state tuning in the form of a double-peaked ITD tuning curve, with one peak near the normal best ITD value determined from the location of the visual receptive field of the site and the other peak corresponding to the learned responses acquired during prism experience (Fig. 10A). While recording at the tectal site, AP-5 was applied in the ICX on the corresponding transect at a site with matched ITD tuning. During periods of AP-5 iontophoresis, both normal and learned responses were blocked equally. The effect of AP-5 at this site is in sharp contrast with the preferential blockade of learned responses observed at every site tested with the same technique in young $(<115 \mathrm{~d}$ of age) prism-reared owls (Feldman et al., 1996). A representative example of the effect of AP-5 measured using this technique in a young owl is shown in Figure $10 B$.

The time course for the loss of asymmetric blockade by AP-5 was characterized by plotting for each site the difference between the blockade of normal versus learned responses as a function of days of prism experience (Fig. 11). For the experiments reported in this paper (circles), asymmetric AP-5 effects ( filled circles) were observed at $\sim 60 \%$ of sites before $215 \mathrm{~d}$ of age (154 d of prism experience). After $235 \mathrm{~d}$ of age (175 d of prism experience), no significantly asymmetric AP-5 effects were observed. For experiments reported previously, using the method of recording responses in the tectum and applying antagonists in the ICX (squares) (Feldman et al., 1996), asymmetric blockade of responses was observed consistently at $<115 \mathrm{~d}$ of age, the only time points tested. The lone site tested with this method at $336 \mathrm{~d}$ of age showed a loss of this asymmetry (Fig. 10 $\mathrm{A}$ ).

The disappearance of the pharmacological difference between 

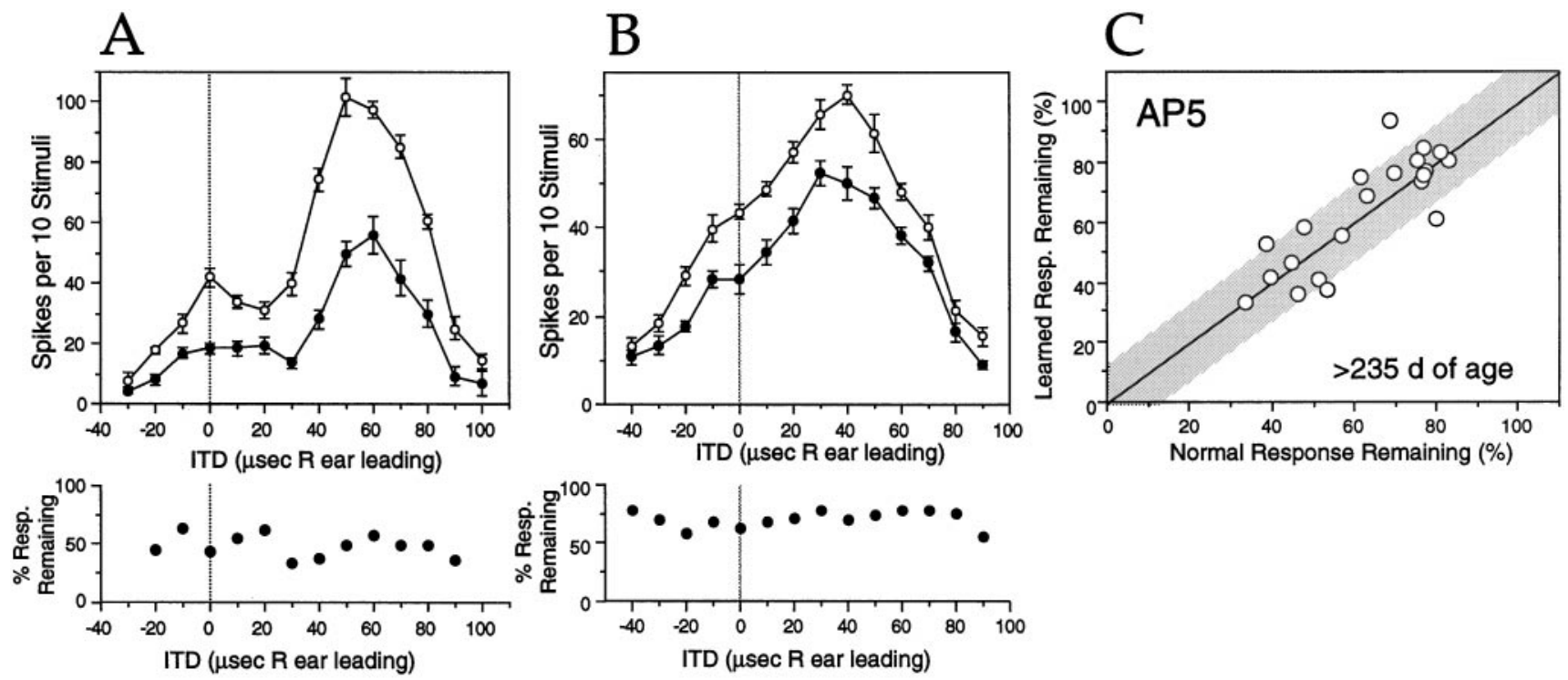

Figure 9. Effect of AP-5 on ITD tuning curves after $>175 \mathrm{~d}$ of prism experience. A, Effect of AP-5 (closed circle, $25 \mathrm{nA})$ at a site in the lateral ICX with ITD tuning typical of that observed after $>175 \mathrm{~d}$ of prism experience. The owl had $259 \mathrm{~d}$ of prism experience. $B$, Another example of the effect of AP-5 at a site in the lateral ICX in a different owl after $386 \mathrm{~d}$ of prism experience. $C$, Effect of AP-5 on normal and learned responses for all sites tested in owls with $>175 \mathrm{~d}$ of prism experience. All sites had mean responses to the normal ITD range that were $>20 \%$ of the maximum response. Gray region, Normal range of blockade asymmetry observed with AP-5 in normal owls (from Fig. 3D).

normal and learned responses seemed to reflect a decrease in the AP-5 sensitivity of learned responses rather than an increase in the AP-5 sensitivity of normal responses. This was determined by calculating the mean blockade by AP-5 of normal and learned responses for all sites in owls with $<175 \mathrm{~d}$ of prism experience versus those with $>175 \mathrm{~d}$ of prism experience (Table 1). This analysis indicated that the AP-5 sensitivity of learned responses became reduced in the older owls, whereas that of normal responses remained constant. Moreover, normal responses in transition state ITD tuning curves appeared to exhibit the same AP-5 sensitivity that normal responses exhibited measured in the lateral half of the ICX in normal adults (Table 1). Together, these data suggest that until $\sim 235 \mathrm{~d}$ of age (175 $\mathrm{d}$ of prism experience), NMDA receptors contribute significantly more to the expression of learned responses than to either normal responses of the same units or normal responses measured in normal owls. With further prism experience, the contribution of NMDA receptors to learned responses decreases to the level observed for normal responses.

\section{DISCUSSION}

Pharmacology during early stages of prism experience

These results demonstrate that, consistent with our previous study (Feldman et al., 1996), learned auditory responses induced in juvenile owls by altered visual experience are pharmacologically distinct from normal responses expressed by the same ICX neurons. In prism-reared owls $<235 \mathrm{~d}$ of age (175 d of prism experience), NMDA receptor-specific levels of AP-5 preferentially reduced learned responses relative to normal responses at the majority of ICX sites expressing both types of responses (Figs. 5-7). In contrast, CNQX reduced normal and learned responses equally at ICX sites, including sites at which AP-5 blocked learned responses preferentially (Fig. 8). These results indicate that the differential blockade of learned responses by AP-5 reflects a pharmacological difference between normal and learned responses and not a difference in the accessibility of relevant synapses to iontophoresed antagonists. Specifically, the relative contribution of NMDA and non-NMDA, presumably AMPA, receptor currents to ICX responses (the NMDA/AMPA current ratio) must be greater for synapses mediating learned responses than for synapses mediating normal responses. This conclusion predicts that blockade of non-NMDA receptors should block preferentially the expression of normal responses. That we did not observe such an effect with CNQX is most likely because CNQX iontophoresis tended to block both NMDA and non-NMDA receptor currents relatively nonselectively (see Materials and Methods).

Preferential blockade of learned responses by AP-5 was observed at 24 of $41(59 \%)$ ICX sites with transition state ITD tuning, including four of five single-unit sites (Fig. 6C). At the remaining sites, the asymmetry of response blockade across the ITD tuning curve fell within the range observed in normal owls. Why preferential blockade of learned responses was observed only at a subset of ICX sites is not clear. These sites were not distinguished in their latency, location within the ICX, ITD tuning width, or response time course (data not shown). One possibility is that only ICX units that actually integrate distinct inputs representing normal and learned responses exhibit the pharmacological asymmetry, whereas other ICX cells that receive input from this first group do not. Our sample size was too small to detect the $<1$ msec latency difference that would be expected between these two hypothetical groups of neurons.

\section{Synaptic basis for the pharmacological specialization of learned responses}

A number of specializations at the ICX synapses mediating learned responses could be responsible for the increased NMDA/ AMPA current ratio of these responses. Synapses mediating learned responses could be enriched in functional NMDA receptors or could contain NMDA receptors altered in redox state (Aizenman et al., 1989; Hammond et al., 1994), phosphorylation 
A

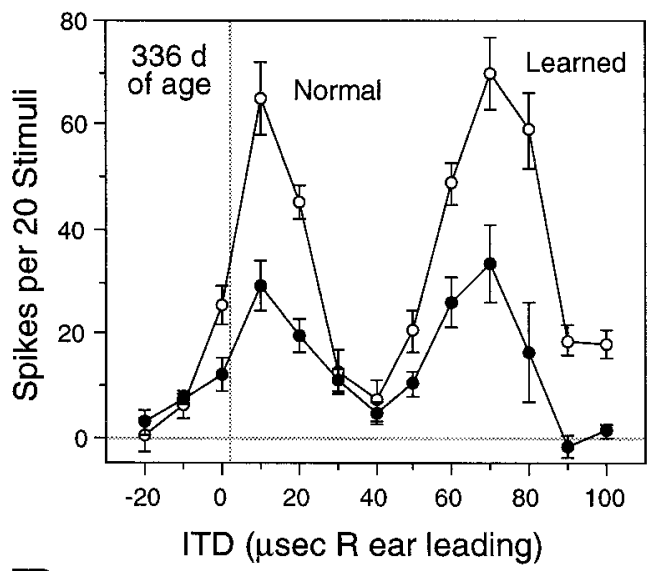

B

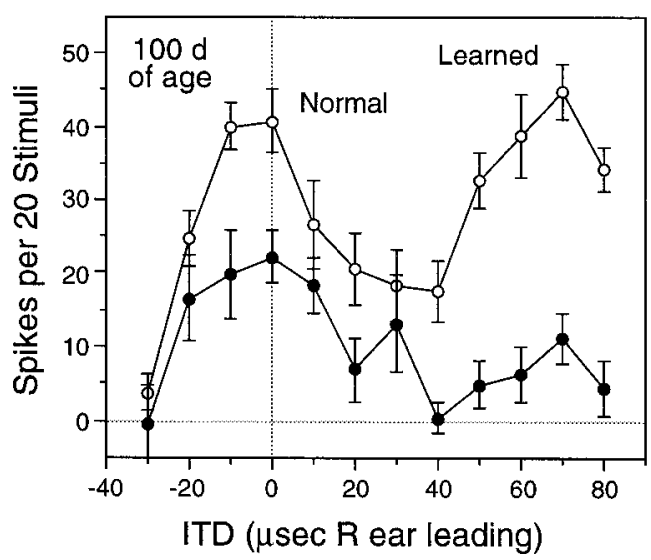

Figure 10. Effect of AP-5 applied in the ICX on transition state ITD tuning recorded in the optic tectum after long and short periods of prism experience. $A$, Effect of AP-5 at a site in a 336-d-old owl after $274 \mathrm{~d}$ of experience with $\mathrm{L} 23^{\circ}$ prisms. The visual receptive field was located at $\mathrm{R} 1^{\circ}$ azimuth, $+2^{\circ}$ elevation. Normal and Learned response peaks, inferred from the location of the visual receptive field, are indicated. The doublepeaked shape is often observed for transition state ITD tuning curves in the tectum (Brainard and Knudsen, 1995; Feldman, 1997). Open circles, Control and recovery periods; filled circles, responses at the tectal site measured during periods of AP-5 iontophoresis (25 nA) at an ICX site on the 0 transect with matched ITD tuning. Error bars indicate SEM across multiple 20 repetition tuning curves. Note that AP-5 applied in the ICX produced equal blockade of normal and learned responses at this tectal site. $B$, Effect of AP-5 at a representative tectal site in a 100-d-old owl after $37 \mathrm{~d}$ of experience with $\mathrm{L} 23^{\circ}$ prisms. The visual receptive field was located at $0^{\circ}$ azimuth, $+3^{\circ}$ elevation. AP-5, 15-25 nA. Data are from Feldman et al. (1996).

state (Lieberman and Mody, 1994; Wang et al., 1994; Wang and Salter, 1994), or receptor subunit composition (Monyer et al., 1992; Flint et al., 1997), any of which can increase the amplitude or duration of the NMDA receptor current. Conversely, the number or effectiveness of AMPA receptors at these synapses may be reduced, thereby increasing the proportion of synaptic current passing through NMDA receptors.

Another possibility is that factors extrinsic to the synapse itself could modulate NMDA receptor currents by virtue of their voltage dependence. For example, if less inhibition impinges on an ICX neuron during learned responses than during normal responses, NMDA receptor activation during learned responses might be greater because the neuron would be more depolarized (Kanter et al., 1996; Kotak and Sanes, 1996). A recent report suggests that ICX neurons do in fact receive less GABAergic inhibition during learned responses than during normal responses, lending support to this hypothesis (Zheng and Knudsen, 1997).

\section{Comparison with ICX pharmacology inferred by recording in the optic tectum}

In our previous study (Feldman et al., 1996), we inferred the pharmacology of ICX circuits mediating normal and learned responses by applying antagonists iontophoretically in the ICX and recording responses downstream in the tectum. Results using this approach were similar to those reported in this study with two exceptions. First, AP-5 application caused a preferential blockade of learned responses at all tectal sites, as opposed to only $59 \%$ of ICX sites in the current experiments. This difference probably reflects the integration of inputs from many ICX neurons by neurons in the tectum.

Second, CNQX application in the ICX caused a small but significant preferential blockade of normal responses measured in the tectum, whereas it blocked both normal and learned responses equally when measured in the ICX. This difference may reflect an effective dose of CNQX that was lower and therefore more selective for blocking non-NMDA receptors in the previous study. This possibility is likely because many of the ICX neurons that projected to the tectal recording sites in that study would have been located some distance from the site of iontophoresis and thus would have been subjected to a relatively low dose of CNQX. In contrast, in the present study, recordings were made through the iontophoresis electrode, and therefore synapses of the recorded neurons were presumably close to the site of drug injection.

\section{Pharmacology after long periods of prism experience}

After $\sim 235 \mathrm{~d}$ of age (175 d of prism experience), AP-5 no longer preferentially blocked learned responses and instead blocked responses uniformly across ITD tuning curves (Figs. 9-11). This acquisition of equal AP-5 sensitivity for learned and normal responses seemed to reflect a reduction in the AP-5 sensitivity of learned responses and not an increase in the AP-5 sensitivity of normal responses (Table 1). Thus, learned responses, once they have been induced by experience-dependent processes, exhibit two major pharmacological features. (1) They initially exhibit a high NMDA/AMPA current ratio, and (2) with extended periods of prism experience, this ratio declines to the ratio observed for normal responses. Unfortunately, because relatively few sites were tested after $160 \mathrm{~d}$ of age (Fig. 10B), we cannot determine whether the decline of the NMDA/AMPA receptor current ratio of learned responses is gradual or whether a sudden change occurs at $\sim 235 \mathrm{~d}$ of age. In addition, because all owls had prisms attached at the same age, we cannot distinguish whether the decline of the NMDA/AMPA current ratio is related to the developmental age of the animal or instead to the duration of prism experience.

\section{Possible mechanisms for the maturation of learned response pharmacology}

The synaptic mechanisms that underlie the eventual attainment of normal pharmacology by learned responses are not known. Three general mechanisms are possible: an age- or activity- 


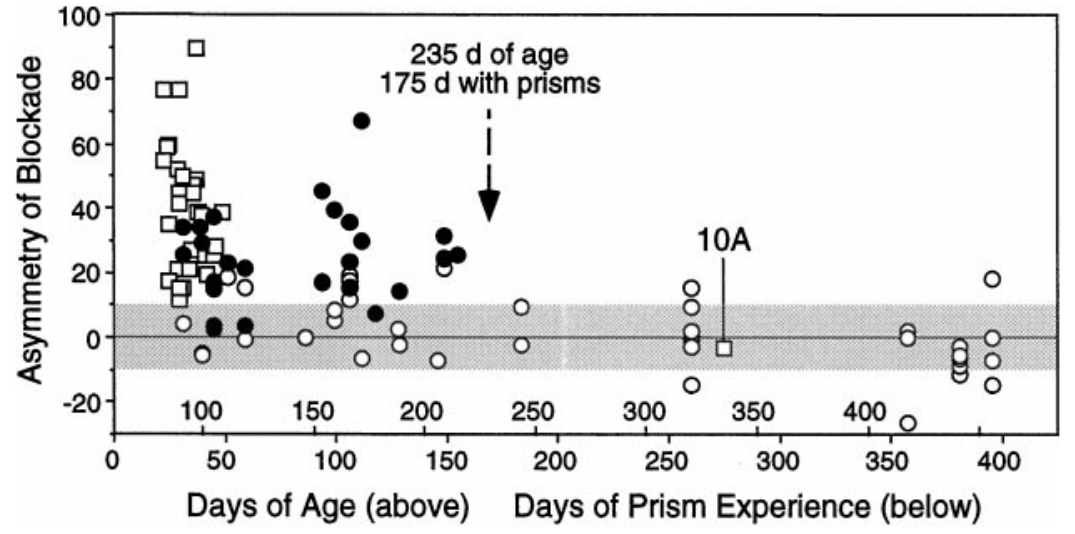

Figure 11. Asymmetry of blockade produced by AP-5 as a function of age and days of prism experience. The $y$-axis shows the percent of responses remaining during AP-5 application for normal responses minus that for learned responses; $100 \%$ indicates selective blockade of learned responses, and $0 \%$ indicates equal blockade of normal and learned responses. Gray region, Normal range of blockade asymmetry observed with AP-5 in the ICX of normal owls (Fig. 3); squares, effects of AP-5 applied in the ICX on transition state ITD tuning recorded in the tectum (Feldman et al., 1996); 10A, site shown in Figure 10 A; circles, effects of AP-5 observed by recording locally in the ICX; filled circles, sites with significantly asymmetric AP-5 effects; open circles, sites with no significant asymmetry.

\begin{tabular}{|c|c|c|c|c|}
\hline & \multicolumn{2}{|l|}{$\begin{array}{l}\text { Response } \\
\text { blockade }^{a}\end{array}$} & \multirow{2}{*}{$\begin{array}{l}\text { No. of } \\
\text { sites }\end{array}$} & \multirow{2}{*}{$\begin{array}{l}\text { Mean ejection } \\
\text { current }(\mathrm{nA})^{b}\end{array}$} \\
\hline & Normal & Learned & & \\
\hline Normal adults ${ }^{c}$ & $39.2 \pm 16$ & & 14 & $26 \pm 11$ \\
\hline \multicolumn{5}{|l|}{ Prism-reared owls ${ }^{d}$} \\
\hline$<175$ d experience & $37.5 \pm 16$ & $54.9 \pm 14$ & 41 & $24 \pm 9$ \\
\hline$>175 \mathrm{~d}$ experience & $37.9 \pm 16$ & $36.4 \pm 19$ & 21 & $25 \pm 9$ \\
\hline
\end{tabular}

${ }^{a}$ Percent of control response blocked by AP-5 iontophoresis (mean $\pm \mathrm{SD}$ ).

${ }^{b}$ Range for all groups, $10-40 \mathrm{nA}$. If multiple ejection currents were tested at a single site, results of the median ejection current were used for this analysis.

${ }^{c}$ Sites in the lateral half of the ICX.

${ }^{d}$ Sites in the lateral half of the ICX with transition state ITD tuning.

dependent decline in NMDA receptor currents at the synapses mediating learned responses, an age- or activity-dependent increase in AMPA receptor currents at these synapses, or an increase in inhibition or other factors extrinsic to the synapse that would hyperpolarize the cell during learned responses and thereby reduce NMDA receptor currents via their voltage dependence.

The first mechanism, a decline in NMDA receptor currents, occurs during early development in many brain regions. Immature synapses exhibit NMDA receptor currents with durations that are several-fold longer than those in adults, and these durations subsequently shorten in an activity-dependent manner (Carmignoto and Vicini, 1992; Hestrin, 1992; Ramoa and McCormick, 1994; Crair and Malenka, 1995). This mechanism, which may reflect a switch in NMDA receptor subunit expression (Flint et al., 1997), is thought to underlie the rapid developmental decline in the proportion of visual responses mediated by NMDA receptors in the visual cortex of the kitten over the first few weeks of life (Tsumoto et al., 1987; Fox et al., 1989, 1991, 1992). In the barn owl, newly functional ICX synapses mediating learned responses may recapitulate this progression from longer to shorter NMDA receptor currents, although on a slower time scale than observed during early development.

The second mechanism, an increase in AMPA receptor currents, has also been suggested to occur during early development. In many systems, immature glutamatergic synapses appear to express only NMDA receptor currents and lack AMPA receptor currents entirely. Because the NMDA receptor current is voltage dependent, such synapses do not pass current while the postsyn- aptic cell is at a hyperpolarized resting potential and therefore have been termed "silent synapses." Silent synapses are prevalent at early stages of development in the CA1 region of the hippocampus of the rat (Isaac et al., 1995; Liao et al., 1995; Durand et al., 1996), the barrel cortex of the rat (Isaac et al., 1997), and the optic tectum of Xenopus laevis (Wu et al., 1996). AMPA receptor currents subsequently appear at these synapses and increase in magnitude, causing a shift from synapses with purely NMDAergic pharmacology to synapses with the mature combination of both AMPA and NMDA receptors. This developmental accumulation of AMPA receptor currents may reflect ongoing LTP of immature synapses, because experimental induction of LTP at silent synapses causes the appearance of AMPA receptor currents (Isaac et al., 1995, 1997; Liao et al., 1995; Durand et al., 1996).

If silent synapses existed in the ICX of the owl or were formed during prism experience (see below), potentiation of a subset of these synapses to mediate learned responses would create a population of synapses that were rich in NMDA receptors but contained enough AMPA receptor currents to generate a reliable postsynaptic response. Learned responses mediated by such synapses would have a higher NMDA/AMPA receptor current ratio than would synapses mediating normal responses. Over longer periods of prism experience, additional potentiation could increase the AMPA receptor component of learned responses until the NMDA/AMPA receptor current ratio reached that of normal responses.

The final mechanism, an increase in inhibition, also occurs during early development in some systems, resulting in a decrease in NMDA receptor currents (Kotack and Sanes, 1996; Ben-Ari et al., 1997). If inhibitory circuits in the ICX were modified during prism experience at a slower rate than excitatory circuits, inhibitory inputs to ICX neurons during learned responses might be small initially and grow larger with additional prism experience. This progression could lead to an NMDA/AMPA current ratio for learned responses that is initially high and then declines to normal.

\section{Correlation with the formation of new synaptic connections}

In the systems described above, the progression from a high initial NMDA/AMPA receptor current ratio to a lower ratio occurs during early development, soon after glutamatergic synapses are formed. In contrast, synapses mediating learned responses in the system studied here become functional relatively late in development, well after ICX circuits are formed (Feldman and Knudsen, 1997). Why should these synapses 
recapitulate the early maturational process? One possibility is suggested by results showing that the topography of the anatomical projection from the ICCls to the ICX is altered during prism experience such that each ICX site acquires abnormal inputs from ICCls regions representing the learned range of ITDs (Feldman and Knudsen, 1997). This finding suggests that new synapses are created during prism experience to mediate learned responses. If such synapses were created with either long duration NMDA receptor currents or with a lack of AMPA receptor currents, as during early development, then learned responses would exhibit a high NMDA/AMPA current ratio. Subsequent maturation of these new synapses, either by the shortening of NMDA receptor current duration or by the addition of AMPA receptor currents, would cause an eventual reduction in the NMDA/AMPA current ratio.

\section{Factors triggering the maturation of learned response pharmacology}

Although the acquisition of normal pharmacology by learned responses after long periods of prism experience may result from a gradual activity-dependent maturation of ICX synapses, as proposed in the models above, it may alternatively be triggered by an extrinsic maturational signal occurring at $\sim 235 \mathrm{~d}$ of age (Fig. 11). This age is also associated with sexual maturation (E. I. Knudsen, unpublished observations) and with a dramatic reduction in the capacity for abnormal visual experience to alter ITD tuning and sound localization behavior (Brainard and Knudsen, 1998). This correlation suggests that the acquisition of normal pharmacology by learned responses may be triggered by hormonal signals or other factors associated with the close of the sensitive period for plasticity.

\section{REFERENCES}

Aizenman E, Lipton SA, Loring RH (1989) Selective modulation of NMDA responses by reduction and oxidation. Neuron 2:1257-1263.

Bear MF, Cooper LN, Ebner FF (1987) A physiological basis for a theory of synapse modification. Science 237:42-48.

Ben-Ari Y, Khazipov R, Leinekugel X, Caillard O, Gaiarsa J-L (1997) $\mathrm{GABA}_{\mathrm{A}}, \mathrm{NMDA}$, and AMPA receptors: a developmentally regulated "menage a trois." Trends Neurosci 20:523-529.

Brainard MS, Knudsen EI (1993) Experience-dependent plasticity in the inferior colliculus: a site for visual calibration of the neural representation of auditory space in the barn owl. J Neurosci 13:4589-4608.

Brainard MS, Knudsen EI (1995) Dynamics of visually guided auditory plasticity in the optic tectum of the barn owl. J Neurophysiol 73:595-613.

Brainard MS, Knudsen EI (1998) Sensitive periods for visual calibration of the auditory space map in the barn owl optic tectum. J Neurosci, in press.

Carmignoto G, Vicini S (1992) Activity-dependent decrease in NMDA receptor responses during development of the visual cortex. Science 258:1007-1011.

Cline HT (1991) Activity-dependent plasticity in the visual systems of frogs and fish. Trends Neurosci 14:104-111.

Collingridge GL, Bliss TVP (1987) NMDA receptors-their role in long term potentiation. Trends Neurosci 10:288-293.

Constantine-Paton M, Cline HT, Debski E (1990) Patterned activity, synaptic convergence, and the NMDA receptor in developing visual pathways. Annu Rev Neurosci 13:129-154.

Crair MC, Malenka RC (1995) A critical period for long-term potentiation at thalamocortical synapses. Nature 375:325-328.

Dudek SM, Bear MF (1992) Homosynaptic long-term depression in area CA1 of hippocampus and effects of $N$-methyl-D-aspartate receptor blockade. Proc Natl Acad Sci USA 89:4363-4367.

Durand GM, Kovalchuk Y, Konnerth A (1996) Long-term potentiation and functional synapse induction in developing hippocampus. Nature 381:71-75.

Feldman DE (1997) Anatomical and pharmacological correlates of learning in the neural representation of auditory space in the barn owl. $\mathrm{PhD}$ thesis, Stanford University.

Feldman DE, Knudsen EI (1994) NMDA and non-NMDA glutamate receptors in auditory transmission in the barn owl inferior colliculus. J Neurosci 14:5939-5958.

Feldman DE, Knudsen EI (1995) Learned responses in the external nucleus of the owl's inferior colliculus (ICX) are preferentially mediated by NMDA receptors. Soc Neurosci Abstr 21:673.

Feldman DE, Knudsen EI (1997) An anatomical basis for visual calibration of the auditory space map in the barn owl's midbrain. J Neurosci 17:6820-6837.

Feldman DE, Brainard MS, Knudsen EI (1996) Newly learned auditory responses mediated by NMDA receptors in the owl inferior colliculus. Science 271:525-528.

Flint AC, Maisch US, Weishaupt JH, Kriegstein AR, Monyer H (1997) NR2A subunit expression shortens NMDA receptor synaptic currents in developing neocortex. J Neurosci 17:2469-2476.

Fox K, Sato H, Daw N (1989) The location and function of NMDA receptors in cat and kitten visual cortex. J Neurosci 9:2443-2454.

Fox K, Daw N, Sato H, Czepita D (1991) Dark-rearing delays the loss of NMDA-receptor function in kitten visual cortex. Nature 350:342-344.

Fox K, Daw N, Sato H, Czepita D (1992) The effect of visual experience on development of NMDA receptor synaptic transmission in kitten visual cortex. J Neurosci 12:2672-2684.

Hammond C, Crepel V, Gozlan H, Ben-Ari Y (1994) Anoxic LTP sheds light on the multiple facets of NMDA receptors. Trends Neurosci $17: 497-503$.

Hestrin S (1992) Developmental regulation of NMDA receptormediated synaptic currents at a central synapse. Nature 357: 686-689.

Isaac JTR, Nicoll RA, Malenka RC (1995) Evidence for silent synapses: implications for the expression of LTP. Neuron 15:427-434.

Isaac JTR, Crair MC, Nicoll RA, Malenka RC (1997) Silent synapses during development of thalamocortical inputs. Neuron 18:269-280.

Kanter ED, Kapur A, Haberly LB (1996) A dendritic $\mathrm{GABA}_{\mathrm{A}^{-}}$ mediated IPSP regulated facilitation of NMDA-mediated responses to burst stimulation of afferent fibers in piriform cortex. J Neurosci 16:307-312.

Katz LC, Shatz CJ (1996) Synaptic activity and the construction of cortical circuits. Science 274:1133-1138.

Kirkwood A, Dudek SM, Gold JT, Aizenman CD, Bear MF (1993) Common forms of synaptic plasticity in the hippocampus and neocortex in vitro. Science 260:1518-1521.

Knudsen EI, Knudsen PF (1983) Space-mapped auditory projections from the inferior colliculus to the optic tectum in the barn owl (Tyto alba). J Comp Neurol 218:187-196.

Kotack VC, Sanes D (1996) Developmental influence of glycinergic transmission: regulation of NMDA receptor-mediated EPSPs. J Neurosci 16:1836-1843.

Liao D, Hessler N, Malinow R (1995) Activation of postsynaptically silent synapses during pairing-induced LTP in CA1 region of hippocampal slice. Nature 375:400-404.

Lieberman DN, Mody I (1994) Regulation of NMDA channel function by endogenous $\mathrm{Ca}^{2+}$-dependent phosphatase. Nature 369:235-239.

Monyer H, Sprengel R, Schoepfer R, Herb A, Higuchi M, Lomeli H, Burnashev N, Sakmann B, Seeburg P (1992) Heteromeric NMDA receptors: molecular and functional distinction of subtypes. Science 256:1217-1221.

Mulkey RM, Malenka RC (1992) Mechanisms underlying induction of homosynaptic long-term depression in area CA1 of the hippocampus. Neuron 9:967-975.

Nicoll RA, Malenka RC, Kauer JA (1990) Functional comparison of neurotransmitter receptor subtypes in mammalian central nervous system. Physiol Rev 70:513-565.

Olsen JF, Knudsen EI, Esterly SD (1989) Neural maps of interaural time and intensity differences in the optic tectum of the barn owl. J Neurosci 9:2591-2605.

Ramoa AS, McCormick DA (1994) Enhanced activation of NMDA receptor responses at the immature retinogeniculate synapse. J Neurosci 14:2098-2105. 
Salt TE, Eaton SA (1989) Function of non-NMDA receptors and NMDA receptors in synaptic responses to natural somatosensory stimulation in the ventrobasal thalamus. Exp Brain Res 77: $646-652$.

Salt TE, Meier CL, Seno N, Krucker T, Herrling PL (1995) Thalamocortical and corticocortical excitatory postsynaptic potentials mediated by excitatory amino acid receptors in the cat motor cortex in vivo. Neuroscience 64:433-442.

Shatz CJ (1990) Impulse activity and the patterning of connections during CNS development. Neuron 5:745-756.

Tsumoto T, Hagihara K, Sato H, Hata Y (1987) NMDA receptors in the visual cortex of young kittens are more effective than those of adult cats. Nature 327:513-514.
Wagner H, Takahashi TT, Konishi M (1987) Representation of interaural time difference in the central nucleus of the barn owl's inferior colliculus. J Neurosci 7:3105-3116.

Wang L-Y, Orser BA, Brautigan DL, McDonald JF (1994) Regulation of NMDA receptors in cultured hippocampal neurons by protein phosphatases 1 and 2A. Nature 369:230-232.

Wang Y-T, Salter MW (1994) Regulation of NMDA receptors by tyrosine kinases and phosphatases. Nature 369:233-235.

Wu G-Y, Malinow R, Cline HT (1996) Maturation of a central glutamatergic synapse. Science 274:972-976.

Zheng WM, Knudsen EI (1997) Role of GABAergic inhibition in experience-dependent plasticity in the inferior colliculus of the barn owl. Soc Neurosci Abstr 23:288.12. 